\title{
Interior Design Teaching Methodology During the Global COVID-19 Pandemic
}

\begin{abstract}
In March 2020, the World Health Organization officially announced the COVID-19 outbreak as a global Pandemic (WHO, 2020). During this time, the United Arab Emirates (UAE) introduced national preventative measures to slow the spread of the deadly virus by announcing the closure of schools and higher education institutions, and the commitment of online learning. Teaching faculty at the College of Arts and Creative Enterprises (CACE) at Zayed University were suddenly facing the challenge of teaching design through a distance learning approach. As educators of interior design, the authors were part of the team tasked to find ways to teach design without physical contact with the students nor access to campus facilities traditionally used to run the program and its associated courses. This paper charts the pedagogy approach that the authors adopted as a response to the national lockdown. As design faculty, the authors felt that, despite the restrictions imposed on society because of COVID-19 pandemic, it was still possible to explore other alternatives for a particular course, the senior capstone project. The main intention was to successfully fulfil the course learning outcomes and provide students with a suitable pedagogy continuity to the learning process commenced prior to the lockdown.
\end{abstract}

Keywords: interior design, online pedagogy, virtual reality, teaching under COVID-19, online teaching design, online virtual exhibition 


\section{Introduction}

Design studio education is deeply rooted in one-on-one teaching activities between the faculty and each student. Many present design disciplines in different high educational models, ranging from urban design, architecture, interior design, graphic design, fashion, and digital media design; share the attribute of teaching through design studio (Crowther, 2013; McCarthy \& De Almeida, 2002). As such, many design educators regard the online or blended learning environment as inadequate (Fleischmann, 2016; Mohammed, 2017; Saghafi et al., 2012).

Teaching online is a new concept at College of Arts and Creative Enterprises (CACE) at Zayed University. It was introduced as a response to the COVID-19 pandemic at the end of March 2020. Using online as a learning platform for teaching art and design courses has seldom been attempted. When the new mandate was announced by the university upper administration, many design teaching faculties at the college asked themselves the question: How can design be taught through online medium? Interior design teaching and learning is usually associated with long, lively group, and one-on-one critiques, using reams of tracing paper laid over the large drawing, working with materials, and constructing-deconstructing physical models. Suddenly, we were all thrown into a world where all these interactions previously taken for granted were no longer accessible. Interactions such as basic human face-to-face communications became one of the greatest challenges, in addition to not having the opportunity to reinforce expectations and instantly clarify misunderstandings (Conaway et al., 2005). In fact, some faculty even felt that online courses could decrease the quality of the learning experience and reduce the effectiveness of learning (Ubell, 2016).

The paper directly responds to the initiated call on pandemic effect on interior and architecture practice by taking a pedagogical angle and an educational perspective. The study assesses and reflects on alternative implemented measures towards capstone project dissemination. Taking into consideration the specific demographics of the participants, the paper evaluates the positive and negative attributes of online capstone project dissemination and the use of VR platforms as an alternative pedagogy method alongside other traditionally established modes. 


\section{Design Studio: Between Tradition, Online and Virtual Reality}

\section{Design studio doctrine: Brief overview}

The discipline of architecture and interior design education are known to associate themselves with the design studio approach. The terminology design studio refers to both the implemented pedagogy and the physical environment. Studio-based teaching model draws back from the apprenticeship model of education (Fisher, 2000); and intends to reflect the collaborative workplace environment within the university learning setting (McClean, 2009). Its origins go back to two movements, the Ecole des Beaux-Arts (19th century) and the Bauhaus (early 20th century) (Lueth, 2008). Modern design educational principles advocates for combining arts with up-to-date practices (Nerdinger, 1985), through a range of learning methodology that brings together lecture courses (theory) and workshops (practice) (Gropius, 1965; Gropius, 1968). "Compared to typical classroom scenarios, studios are active sites where students are engaged intellectually and socially, shifting between analytic, synthetic, and evaluative models of thinking in different sets of activities (drawing, conversing, model-making)" (Dutton, 1987, p. 16).

The studio learning methods in the architecture and interior design education continues to prevail today. Over generations, design studios became an example of signature pedagogy; a concept defined by Lee Shulman as "types of teaching that organize the fundamental ways in which future practitioners are educated for their new professions" (Shulman, 2005, p. 2). This made itself into the doctrine of design education across the globe. For instance, in the United Kingdom, the Royal Institute of British Architects (RIBA) and the Architects Registration Board (ARB), state in their 2011 validation criteria for undergraduate and taught postgraduate courses in architecture that they should consist of at least $50 \%$ design studio projects (RIBA, 2014). More recently, in 2018, the American Institute of Architecture Students (AIAS) announced a partnership with the National Architectural Accreditation Board (NAAB) to promote healthy studio cultures in the architectural schools (AIAS, 2018).

Despite present literature that criticises possible rising trends within architectural studio education (Datta, 2007; Dutton, 1987; Groat \& Ahrentzen, 1996; Salama \& El-Attar, 2010; Stratigakos, 2016; Webster, 2006; Webster, 2008), until very recently it was the most singular followed approach in most design schools. Studio format and particularities are often reshaped in response to the school and followed program ethos, but generally speaking, all perform to four 
main characteristics defined by Donald Schön (1987) described in Educating the Reflective Practitioner: a built learning and teaching environment; a learning and teaching method; programs and / or activities; and a culture created by the inhabitants-learners and faculty interaction.

\section{Virtual design studio: Brief overview}

The notion of virtual design studio is not a new approach. It has been explored to some extent since the mid 1990s powered by the evolution and the rise in popularity and accessibility of computing power and digital technologies (Kvan, 2001; Wojtowicz, 1995).

The first online educational platforms go back to the 1960 s at the University of Illinois (Bitzer, 1986) The platform was used until 1990s. This notion preceded the modern internet and introduced many of the concepts central to today's online interactions, such as chat rooms and online lectures (Bitzer, 1986). Other examples of distant learning is college-by-radio at the University of Louisville (Dwayne $\&$ William, 1999) and televised courses at DePaul University (Jason et al., 1987). Virtual learning gained popularity with the rise of the internet and the widespread use of personal computers. One of the first online courses for credits were offered in 1984 by the University of Toronto (Harasim, 1987). Since then, a number of open universities across the globe were founded championing and advocating for the distance learning methodology. Examples include the Open University of Catalonia (1994-to date) (The Open University of Catalonia, n.d.), Jones International University (1999-2015) (Jones International University, n.d.), and the UK Open University (1969-to date) (UK Open University, n.d.).

Despite the criticism and speculation surrounding online virtual studio education, there are a number of precedents for online architecture accredited degrees. Most recently in March 2020, the Guide to Online Schools issued a comprehensive guide to accredited online architecture degrees in the US (GTOS, 2020).

\section{Application of VR technology in the design education}

Virtual reality (VR) is nowadays commonly associated with game design and VR related products (VR goggles). It simulates a threedimensional immersive experience and allows the user to control, navigate and move around a digital environment. In addition to entertainment, VR technology has also been widely used for industrial design, military training, automotive and aerospace design, medical fields, and maintenance and repair avenues. 
(Abulrub, Attridge, \& Williams, 2011; Etheredge, Kunst, \& Sanders, 2013; Mikropoulos \& Eze, 2011; Okechukwu \& Eze, 2011).

The term virtual reality was used by Jaron Lanier (1992) around the 1980s, and later described as an interactive digital simulation that responds to the user's position and action (Sherman \& Craig, 2018). More recently, VR technology is associated with design visualization and viewer/participant interaction or walk-through threedimensional designs. This form of experiencing three-dimensional abstractness is seen as an upgrade to the traditional computeraided design representations (Ran \& Wang, 2011). Another recent prominent, widespread appropriation is the VR experience of many worldwide museums and exhibition collections (Schweibenz, 2019), and more than ever transforming it to a consumer accessible easyto-use technology (Evans, 2018).

The VR use within pedagogy goes back to the 1990s (Abdelhameed, 2013). Since then, there are many precedents of architecture schools integrating VR into design courses curriculum (Kieferle \& Herzberger, 2002). The technology became a tool used to enhance design and representation skills. This included understanding both structure and construction systems (Garcia, Marquez, \& Valverde Vildosola, 2001), remote cooperation and group work (Lang \& Hovestadt, 2003), and setting individualised and articulated design platforms (Kalisperis et al., 2002). And as a pedagogy tool to merge aspects of the conserved past with new designs and communications of the contemporary world; seen as an effective design tool used to complement current prevalence of today's young generation perceived technological competency (Gębczyńska-Janowicz, 2020).

\section{A Case Study: VR Technology in Interior Design Education}

Throughout the literature, there is clear evidence of the studio pedagogy dominance in design and architecture education. This is evident in the number of worldwide institutions that offer bachelor's degree in the field of interior design and architecture in comparison to the number of available online degrees. Further, the author's research showed that there are no accredited online bachelor degree programs currently available in the Middle East and Gulf region (Bachelor Studies, 2020a, 2020b; Great Value Colleges, 2020; Online Schools Center, 2020). The presented case study also excludes the numerous available open and paid online sources and courses, as well as all graduate online degrees. It focuses on the bachelor undergraduate academic level considered as the basic first step for higher degree education. 
The case study also acknowledges the many examples of utilizing virtual reality technology in architecture and design pedagogy as a learning medium. These applications include "ideation, collaborative design, building management and design education" with few present systems that are "designed to support design critique sessions in term of pedagogy outcomes" (Milovanovic et al., 2017, p. 15).

Senior project end of year dissemination is an essential part and an important established outcome in the interior design program. It constitutes part of the course learning outcomes that map into the institution's key performance indicators. VR in this instance was used as a tool and methodology to virtually transport the senior students, visitors, and invited guests back into the boundaries of a familiar space environment-the college's gallery space; thus, crossing and overcoming the physical boundaries imposed by COVID-19. As opposed to simulating environments, it simulated a dissemination experience in a well-known environment through virtual navigation, complementing the other two used traditional methods; e-folios and recorded presentations.

\section{Participants Background}

The UAE is characterised by rapid and far-reaching socio-economic change (Lee, 2006), powered by the commercial exploitation of the nation's oil and gas reserves. This has radically transformed the nation economically and demographically. The local population, despite being the minority, have one of the world's highest per capita GDPs in addition to social benefits such as free healthcare and education (Fox, Mourtada-Sabbah, \& Al-Mutawa, 2006). Zayed University is a federal gender-segregated institution for higher education that follows the American liberal arts college system. It is located in the United Arab Emirates and has two campuses, one in each of its major cities-Abu Dhabi and Dubai. Zayed University is accredited by the Middle States Commission on Higher Education, and the College of Arts and Creative (CACE) holds a substantial equivalence accreditation from the National Association of Schools of Art and Design (Zayed University, n.d.). The college offers a Bachelor of Fine Arts with majors in interior design, graphic design, visual art, and animation design; in addition to a joint bachelor degree in multimedia design with the College of Communication and Media Sciences and the College of Technological Innovation (Zayed University, n.d.). The university is coeducation with two adjacent yet totally separated male and female campuses. The Art and Design Programs are only offered to female students. 
As per the lasted students' institution extracted statistics for Fall 2020, 919 female students are enrolled across the college's five majors on both campuses. $99.13 \%$ of the enrolled students are from a local national population, with only eight international students. 39.5\% (313 students) of the enrolled students' major in Interior Design across junior, intermediate and senior levels. The prevailing local female students' population creates a unique monocultural dynamic, situated in a global international city that markets itself as a centre for art and cultural (Stewart, 2019). The students come from a background that is rich with culture and tradition, yet from conservative family settings. They join the program with very little understanding and minimal exposure to the notion of art and design.

The uniqueness of the presented case study stems from the tools and methodology the authors devised to navigate cultural constraints amidst the imposed COVID-19 restriction. It presents a three-month journey of three faculty members and their 23 interior design graduating students. The usual deployed online video communications and web streaming platforms such as public conference and presentations, widely used internationally and regionally at many private schools and universities were not suited as an alternate platform. Due to cultural measures, the majority of students felt uncomfortable with public appearance. With the use of VR technology, the authors maintained the initially outlined course deliverables, provided graduating students a form of public appearance, and transformed the participating audience back to the boundaries of a familiar environment-the university's gallery space. In addition to allowing for an individualised senior exhibition navigation experience.

\section{Teaching Methodology}

\section{Phase 1: Foundation}

The authors set the same deadlines for the students as if they were having a real physical exhibition. In February, 2020, and unaware of the coming lockdown situation, the authors engaged in phase 1 of the exhibition, assembling a prototype modular system using $40 \mathrm{~mm} \times 40 \mathrm{~mm}$ section timber battens with $18 \mathrm{~cm} \times 122 \mathrm{~cm} \times 244$ $\mathrm{cm}$ uncut MDF sheets for mounting. These exhibition stands were designated as totems, because of their verticality in exhibiting work. 


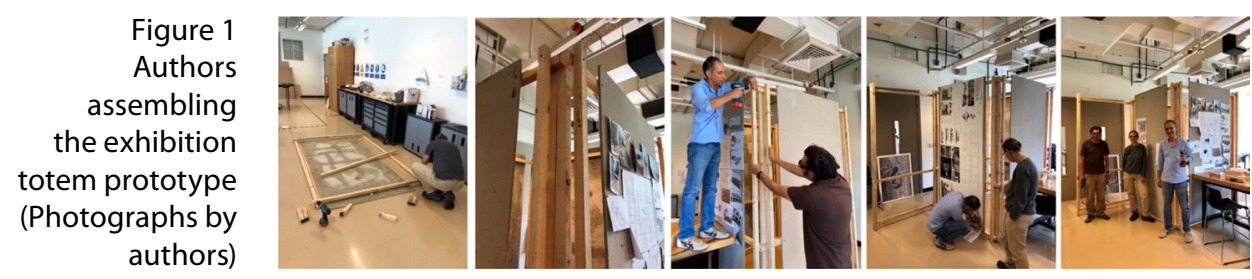

Up to that point, the students were working towards a physical exhibition curated in alliance with the course learning outcomes and deadlines set by the course's syllabus and curriculum. The main assignments were exhibition (poster and physical model), portfolio (in the form of a printed booklet), and presentation (conducted to invited industry experts). By early March, 2020, it became apparent that the pandemic will take place closing the university campus and that all courses will be delivered online. In response, the authors devised new strategies with the intention to maintain the set course deliverables to minimize the learning disruption for the students, thus allowing them to concentrate on their design proposals. The strategy for deliverables remained the same except for the physicality of the content. The exhibition, posters, and models became digital and ephemeral.

\section{Phase 2: Strategy}

Although it could be argued that this would have been a perfect opportunity to design an imaginary gallery, it was decided to digitally represent the College's exhibition space/gallery to keep the familiarity aspect to the students. The gallery now existed in two forms; in the virtual and the real world.

To accompany the virtual exhibition, a website showcasing the graduating students work was built and linked to the virtual exhibition. An online event to invited guests and students' family members commemorated the launch of the exhibition and associated website. All deliverables and deadlines remained as initially envisaged with the following minimal adjustments. First, all models of design proposals, instead of being fabricated were made digitally. Second, booklets, whereas normally printed and bound as physical essays/portfolios were delivered electronically as PDF documents. Third, exhibition posters, whereas normally printed on paper, were delivered electronically as PDF documents. Fourth, student presentations, whereas normally delivered in front of an audience, were delivered as pre-recorded 10-minute presentations. 


\section{Virtual reality (VR) exhibition}

Historically, at the end of every spring semester, the college hosts their traditional end of year showCACE graduation exhibitions featuring students' capstone projects from the college's five majors. This provides an excellent platform to showcase the student's thesis projects to a large audience. It allows for family, friends and industry professionals to see the work, interact with the graduates, and celebrate their achievements. The exhibition is usually inaugurated by the university's upper administration and other distinguished invited guests. The exhibition runs for 4 to 10 days, depending on the venue. The exceptional circumstances of spring 2020 called for a very different situation, as physical gatherings are not possible during the global COVID-19 pandemic. In an attempt to celebrate the achievements of our students, the authors and students prepared and presented a new initiative in the format of a virtual reality (VR) exhibition. The participating members developed an online viewer experience to highlight the work of their studentsVirtual showCACE: Interior Design.

The exhibition was intended to run from launch (early May 2020) until the start of Fall semester (August 2020). The strategy for the virtual online exhibition was to be a platform for internship placement and potential employers to access and view the work of graduating students.

Studies have shown that the visual experience of the visitors to an exhibition is enriched when visitors interact with exhibition space (Sharji, Peng, \&Woods, 2013). The aim was to enhance the exhibition experience by merging the principles of design, architecture, and interactivity supported by digital media on an online platform (Orhun, 2014).

Virtual reality (VR) exhibition in the context of the authors' intention reconstructs an existing gallery space, allowing for exhibits to be displayed and for visitors to interact with the space; giving them a richer, more memorable experience (Chow \& Chan, 2009). Interactive web-based virtual exhibitions allow visitors to experience up to date and high resolution three-dimensional objects along with other layers of information such as text and photographs (Corcoran, Demaine, Picard, Dicaire, \& Taylor, 2002). The visitors can choose what exhibits to see, study objects in close details, change views trajectory, and even manipulate the time of the day to explore how exhibits react to different sun positions. Internet-based virtual exhibitions allow visitors access anytime, anywhere (Su, Yen, \& Zhang, 1998). In addition, visitors can enter the exhibition space through a link from each student's webpage in 
the exhibition website, therefore guaranteeing direct access to the student's own exhibit as the first point of entry, therefore, placing all students exhibit at the front of the exhibition.

\section{exhibition space (Photographs by authors)}

Figure 3

Physical models replaced by digital models (Photograph by Zainab AlBlooki and Maryam Tahir)

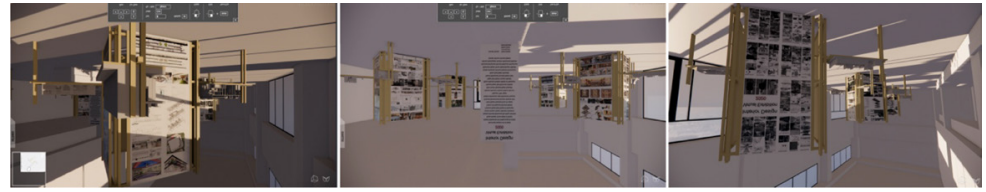

The department's gallery/exhibition space in campus and the previously constructed exhibiting totem were digitally modelled and prepared for virtual implementation using virtual reality immersion software. The physical space, $21 \mathrm{~m} \times 17.5 \mathrm{~m}$ (370 sqm), is rectangular in shape with large south-facing windows. The totems, $1.7 \mathrm{~m} \times 1.7 \mathrm{~m} \times 2.6 \mathrm{~m}$, accommodated 4 vertical faces each housing $1.22 \mathrm{~m} \times 2.44 \mathrm{~m} \times 18 \mathrm{~mm}$ uncut MDF sheet. Each student designed and laid out her work on a vertical poster with the same dimensions as the initial poster previously planned to be printed and attached to each MDF sheet. All these physical dimensions were brought into a 1:1 virtual model of the space, totems, and posters. The only digital scaled down inclusions were digital models of the students' design proposals. These digital models were scaled to fit on a horizontal digital table measuring $1.2 \mathrm{~m} \times 0.5 \mathrm{~m}$.
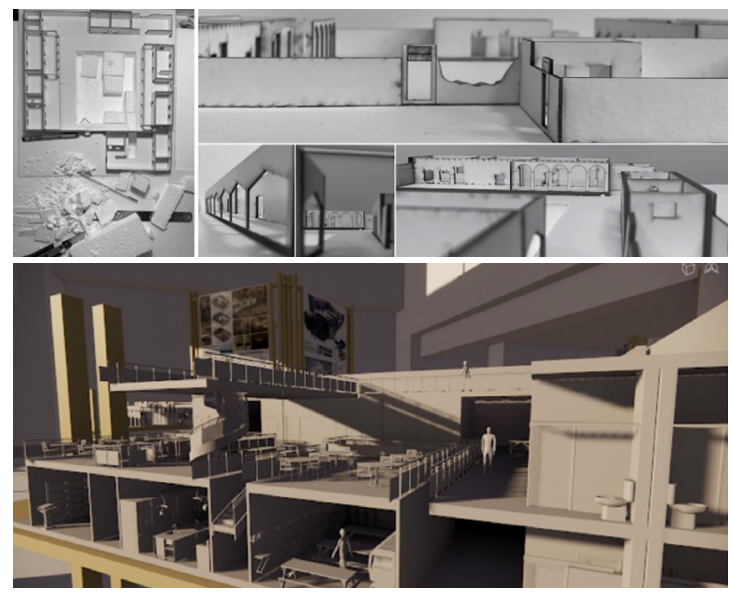

\section{E-folio websites}

During this rapid transformation due to the pandemic, our students redeployed the traditional portfolio into e-portfolio utilising their own branded website. The website became an opportunity to incorporate their work displayed in the virtual exhibition for closer analysis. 
The inverted classroom, which works well with interior design, removes the lecture element by allowing a more one-on-one engagement between the teacher and student (Roehl, Reddy, \& Shannon, 2013). Comparably, a personalised e-folio website conveys the tailored design work of the graduate looking to start a career devoid of the traditional interview process. Both the designer and the reviewer can be within their own comfortable settings discussing and analysing the pros and cons of filling a particular job description. The designer chose to deliver their work in whatever means and space they desired.

Under the pretext of showcasing one's own academic achievements, it was necessary for a student to become an apprentice to elect how, where, and when the content would be the best suit for the mode of delivery. As good design depends on context, the context by which design is delivered becomes as significant. Today's extraordinary times yield an opportunity for graduates to customize the space, context, place, and environment into which they want to deliver their design.

Hybrid media to portray one's own work is best articulated within a digital platform. Learning is noted as an absorbed perception, effectively the relationship between yourself and the physical space becomes the learning space (Boys, 2010). Ultimately, our graduating students collectively and individually made their mark by creating their personalised environments to showcase their best design abilities using the e-folio website platform.

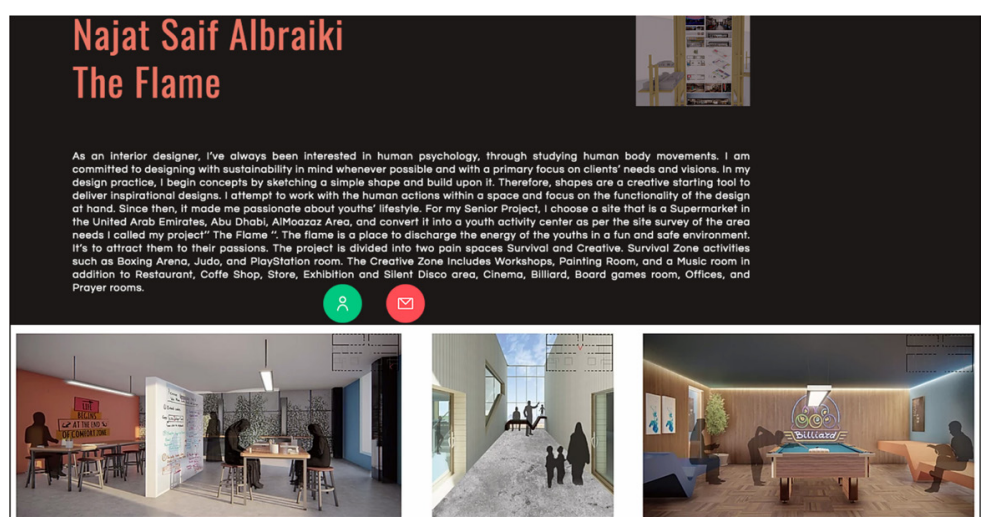

Figure 4

Extract from the student's webpage Najat Saif Albraki (Photographs by authors)

The website was made in parallel, and all work was submitted by the end of April to be able to incorporate the material for the opening on the May 6, 2020, which would have been the real opening of the exhibition if carried out in the physical format. The exhibition was generated using a mixture of different software and digital mediums. 


\section{Recorded presentations}

Another major component of the course assignments is the student presentation of their work. This normally takes the form of a public presentation, whereas students present their design proposals to industry professionals and peers in the form of digital slides. The public presentation format was altered by the authors to recorded presentations. This method is a topical one used by many academic conferences. It provided students with a learning experience possible to directly utilize in the near future with the current observed precedent of many conferences leaning towards electronic presentations. It was felt that recorded film presentations would provide an opportunity for the students to further explore ways to present their design proposals previously not considered. Students used GIF animations, voice-over narratives, film, and sounds in combination with their own drawings to express their design intentions.

It was decided to keep the presentations at no more than 10 minutes as viewers are able to remember $70 \%$ of what is taught in the first 10 minutes (Hartley \& Davies, 1978). The time limit constricts the students, therefore provides a mandate to explore a clear linear cinematic narrative of their projects. Some created neo-realism by inventing a fantastic environment or context in how they told the story-for example, treating the narrative as if it was an inflight airline announcement. Short films making for students' viewing in the academic environment increases their attention and understanding (Kabadayi, 2012).

Also, various online social media applications created a phenomenon of viral videos giving our students a voice that is familiar to them, thus a potential role of "linear narrative cultural influencers" (Brothers \&Wendell, 2016, p. 321).

Figure 5

Diagram showing project phases and timeline of phases (Image by authors)

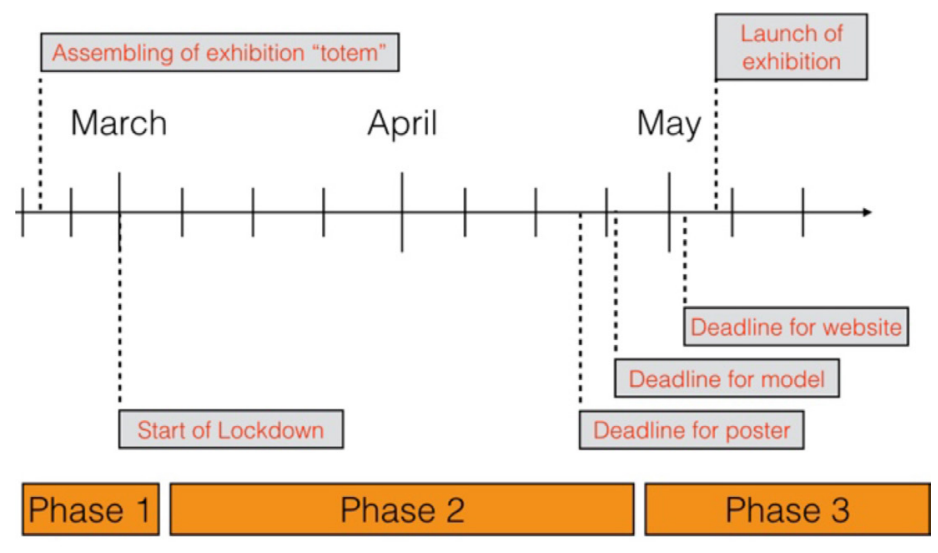




\section{Phase 3: Implementation}

The students digitally submitted their posters for comments around the end of March, 2020. The students' posters were incorporated into the exhibition website along with accompanying texts and contact details for interested employers. The launch of the virtual exhibition was announced and advertised extensively through social media. The event was accessed by over 150 attendees, including alumni and exhibiting students, in addition to CACE faculty, students' family and invited industry professionals from the UAE and other parts of the world.
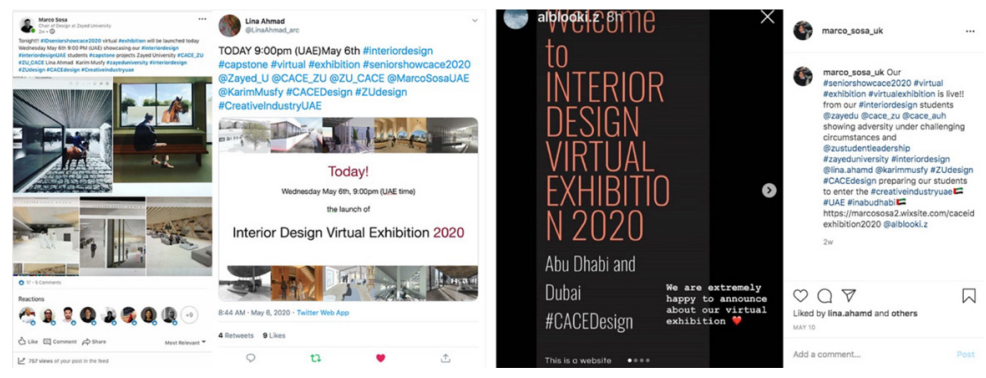

Figure 6

Social media exhibition announcement exposure (Images by authors)

\section{Reflection on the Deployed Framework for Senior Project Dissemination}

The alternate format of virtual reality (VR) exhibition, e-folio websites, and recorded presentations has enabled the authors to successfully complete the course learning outcomes in par with the interior design program learning outcomes. It enabled the authors to successfully mitigate the sudden unexpected imposed change in pedagogy format with minimal deviation from the course brief outlined at the beginning of the semester. This maintaining the same deliverables in the original specified format and minimised and controlling foreseen disturbance and course outline alteration. It also allowed the interior design graduates to virtually interact with the public within the socially acceptable cultural constrains. Twelve students, thus $50 \%$ of the students scored in the accomplished level range ( $80 \%$ and above).

The case study presents an example of an alternate use of democratised technology. It was directly evident how students and their family appreciated the alternate dissemination format. E-folio became one of the platforms students used for internship recruitment by showcasing their work in the context of the class group. Recorded presentations gave students a voice, thus finding a means to interact within the acceptable norms of cultural 
boundaries and tradition. VR exhibition transported students, faculty, and guests into a familiar environment allowing them to virtually navigate and stroll through.

Despite the overall recognised gained benefits, two main adverse attributes surfaced. First, the elimination of physical aspect through virtual delivery took away the direct interaction and encounter with scale and size. The models physicality and perception of large format prints, though simulated in the VR environment, failed to a certain extend to portray the real scale and proportion of an outputted proposal. Second, the students did not have a chance to explore and experience the materiality of the designed spaces, usually explored and captured through physical models. Though environments were digitally simulated, the digital realm does not provide the same spatial experience as when explored through physical encounters.

The success of the experience is echoed in the following statements provided by various participating parties; a testimony to the success of the senior project delivery during the unprecedented global pandemic time.

I am very proud of how the College has adapted in such a short time. A great example is the Interior Design final year submissions. These were not only evaluated with external reviewers through video conferencing, but the interior design faculty also created a virtual exhibition based on our own gallery space. The student work, both 2D and 3D is displayed in this virtual environment where visitors can easily navigate and review the students' hard work. It is a great example of the adaptability and creative thinking within the college during these difficult times. (Dr. Kevin Bandi, Dean of CACE)

At first, I was very disappointed to know that we are ending our senior year away from campus. But we have all made it through and we earned this moment. We have been robbed of celebrating our senior project in the exhibition due to the critical situation, but that might be the best-case scenario because this year we have done it differently. Moving the exhibition virtually was somehow a different experience to all of us. (Interior design graduating student)

To have my project be accessible to family members and friends abroad without having to fly down and see my exhibition in person is remarkable. As a designer who completed her senior project in such extraordinary times, I feel lucky to have gone through such an experience, with 
many lessons learned to carry into the future. This whole experience will be quite an eventful memory to look back to. (Interior design graduating student)

The initiative combines the necessity of the student's individual work with the opportunity of a collaborative environment offered by the existing technologies. Design is a collective learning-activity centered in sharing and confronting ideas and proposals. The virtual exhibit recaps and presents this process and bringing together the work of 23 students to celebrate the conclusion of a very unusual semester. (Dr. Roberto Fabbri, Professor of architecture, University of Monterey, Mexico. Invited Guest)

These young women are now entering the creative economy with a set of skills that is inherently suited for the virtual unknown world we are now in-and will remain in for at least the next two years and beyond. CACE and the professors in the department of Interior Design are creating a hub of skilled designers ready to face any challenge in our current environment-a hub not only for the UAE and the countries of the Arabian Gulf-but for the entire Arab World and beyond. (Dr. Constance VanHorne, Professor of entrepreneurship, Guangdong Technion in Shantou, China. Invited Guest)

\section{Conclusion}

One of the limitations for the process could be argued the missed opportunity to design a new space for the exhibition-a virtual space that could have defied gravity and other 'real' life limitations. By deciding to model the existing gallery, the authors felt that the process allowed for pedagogy continuity-enabling their students to work with a familiar space and exhibition stand. This was of particular importance as it allowed the students to concentrate on the task in hand; their design proposals rather than having the distraction of designing a new virtual gallery space. It was directly evident that students appreciated the consistency and the refrain from altering the submission format. Should the online teaching platform continue, the notion of virtual exhibition design could be incorporated as part of the course deliverables. The international lockdown has abruptly created many limitations. Whereas interior design education tends to demand continuous one to one interactive communication between tutor and student, the presented case study has shown how a challenge was turned into an opportunity. 
COVID-19 pandemic is making the pedagogy profession rethink education, not only through implementing the known, but also discovering new potentials within the interior design education. The answers are not simple nor direct and are requiring educators to step outside their comfort zones into a realm of undefined yet interesting possibilities. Looking at other regional and international precedents (vdf, 2020), the paper also gages questions on possible future changes to current pedagogy practices within Zayed University institution predicted to emerge as a direct result from the recent online and VR senior project dissemination experience. It is the time for the process of design to be negotiated, customised, and tailored into a new individualised progression. Designs now can be criticised or juried utilising online communication across continents. Projects and students' exhibitions that were until very recently a localised on-campus experience, can now be shared with an audience from across the globe, thus creating a wider circle of sociopolitical and cultural audiences. Over and above, the research methodology and pedagogy presents a new intake on the set of literature review under the current lockdown.

\section{References}

Abdelhameed, W. A. (2013). Virtual reality use in architectural design studios: A Case of studying structure and construction. Procedia Computer Science, 25, 220-230. https://doi. org/10.1016/j.procs.2013.11.027

Abulrub, A.-H. G., Attridge, A. N., \& Williams, M. A. (2011). Virtual reality in engineering education: The future of creative learning. 2011 IEEE Global Engineering Education Conference (EDUCON), 751-757. https://doi.org/10.1109/ EDUCON.2011.5773223

AIAS. (2018, April 11). AIAS and NAAB partner to promote healthy studio culture. Retrieved from http://www.aias.org/aiasand-naab-partner-to-promote-healthy-studio-culture/

Bachelor Studies (2020a). Distance learning Bachelor Programs in Architecture 2020. Retrieved from https://www. bachelorstudies.com/Bachelor/Architecture/Distancelearning/

Bachelor Studies (2020b). Distance learning Bachelor Programs in Interior Design 2020. Retrieved from https://www. bachelorstudies.com/Bachelor/Interior-Design/Distancelearning/ 
Bitzer, D. L. (1986). The PLATO project at the University of Illinois. Engineering Education, 77(3), 175-80.

Boys, J. (2010). Towards creative learning spaces: Re-thinking the architecture of post-compulsory education. London: Routledge.

Brothers, D., \& Wendell, A. (2016). Design Films: Implementing video creation techniques into undergraduate design education. Parametricism vs. Materialism: Evolution of Digital Technologies for Development, $8^{\text {th }}$ ASCAAD Conference Proceedings, 321-330.

Chow, S., \& Chan, K. (2009). Reconstruction of photorealistic 3D model of ceramic artefacts for interactive virtual exhibition. Journal of Cultural Heritage, 10(2), 161-173. https://doi. org/10.1016/j.culher.2008.08.011

Conaway, R. N., Easton, S. S., \& Schmidt, W. V. (2005). Strategies for enhancing student interaction and immediacy in online courses. Business Communication Quarterly, 68(1), 23-35. https://doi.org/10.1177/1080569904273300

Corcoran, F., Demaine, J., Picard, M., Dicaire, L., \& Taylor, J. (2002). Inuit3d: An interactive virtual $3 \mathrm{~d}$ web exhibition. Museums and the Web, 18-20.

Crowther, P. (2013). Understanding the signature pedagogy of the design studio and the opportunities for its technological enhancement. Journal of Learning Design, 6(3), 18-28. https://doi.org/10.5204/jld.v6i3.155

Datta, A. (2007). Gender and learning in the design studio. Journal for Education in the Built Environment, 2(2), 21-35. https:// doi.org/10.11120/jebe.2007.02020021

Dutton, T. A. (1987). Design and studio pedagogy. Journal of Architectural Education, 41(1), 16-25. https://doi.org/10.108 0/10464883.1987.10758461

Dwayne, C. D., \& William, M. J. (1999). The University of Louisville. Lexington: University Press of Kentucky.

Etheredge, C., Kunst, E., \& Sanders, A. (2013). Harnessing the GPU for real-time haptic tissue simulation. Journal of Computer Graphics Techniques, 2(2), 28-54. 
Evans, L. (2018). There-emergence of virtual reality. London: Routledge.

Fisher, T. (2000). In the scheme of things: Alternative thinking on the practice of architecture. Minneapolis, MN: University of Minnesota Press.

Fleischmann, K. (2016). Peer assessment: A learning opportunity for students in the creative arts. In C. Nygaard, J. Branch, $\mathrm{P}$ Bartholomew (Eds.), Assessing Learning in Higher Education (pp. 45-58). Faringdon: Libri.

Fox, J., Mourtada-Sabbah, N., \& Al-Mutawa, M. (2006). Globalization and the gulf. London: Routledge.

Gębczyńska-Janowicz, A. (2020). Virtual reality technology in architectural education. World Transactions on Engineering and Technology Education, 18, 24-28.

Garcia, A., Marquez, J., \& Valverde Vildosola, M. (2001). Qualitative contribution of a VR-system to architectural design: why we failed? Proceedings of 6 th Conference on Computer-Aided Architectural Design Research in Asia, 423-428.

Great Value Colleges (2020). 6 most affordable bachelor's in architecture online for 2020. Retrieved from https:// www.greatvaluecolleges.net/rankings/online-bachelorsarchitecture/

Groat, L. N., \& Ahrentzen, S. (1996). Reconceptualizing architectural education for a more diverse future: Perceptions and visions of architectural students. Journal of Architectural Education, 49(3), 166-183. https://doi.org/10.1080/104648 83.1996.10734679

Gropius, W. (1965). The new architecture and the Bauhaus (P. Morton Shand, Trans.). Cambridge, MA.: MIT Press. (Original work published 1935)

Gropius, W. (1968). Apollo in the democracy: The cultural obligation of the architect. New York: McGraw-Hill.

Guide To Online Schools. (2020). Complete guide to an online architecture degree. Retrieved https://www. guidetoonlineschools.com/degrees/architecture

Harasim, L. (1987). Teaching and learning on-line: Issues in computer-mediated graduate courses. Canadian Journal of Educational Communication, 16(2), 117-135. 
Hartley, J., \& Davies, I. (1978). Note-taking: A critical review. Programmed Learning and Educational Technology, 15(3), 207-224. https://doi.org/10.1080/0033039780150305

Jason, L. A., Gruder, C. L., Martino, S., Flay, B. R., Warnecke, R., \&Thomas, N. (1987). Work site group meetings and the effectiveness of a televised smoking cessation intervention. American Journal of Community Psychology, 15(1), 57-72. https://doi. org/10.1007/BF00919757

Jones International University (n.d.). Retrieved from http://www.jiu. edu/

Kabadayi, L. (2012). The role of short film in education. ProcediaSocial and Behavioral Sciences. https://doi.org/10.1016/j. sbspro.2012.06.657

Kalisperis, L., Otto, G., Muramoto, K., Gundrum, J., Masters, R., \& Orland, B. (2002). Virtual reality/space visualization in design education: The VR-desktop initiative. 20th eCAADe Conference Proceeding, 64-71.

Kieferle, J. B., \& Herzberger, E. (2002). Digital year for architects experiences with an integrated teaching concept. 20th eCAADe Conference Proceeding, 88-95.

Kvan, T. (2001). The pedagogy of virtual design studios. Automation in Construction, 10(3), 345-353. https://doi.org/10.1016/ S0926-5805(00)00051-0

Lang, S., \& Hovestadt, L. (2003). An architectural framework within a spatially immersive real-time environment for advanced communication and collaboration. 21 th eCAADe Conference Proceeding, 37-43.

Lanier, J. (1992). Virtual reality: The promise of the future. Interactive Learning International, 8(4), 275-79.

Lee, J. W. (2006). The world health report: Working together for health. Geneva: World Health Organization. Retrieved from http:// www.who.int/whr/2006/en/

Lueth, P. (2008). The architectural design studio as a learning environment: a qualitative exploration of architecture design student learning experiences in design studios from firstthrough fourth-year. lowa: lowa State University. 
McCarthy, S., \& De Almeida, C. M. (2002). Self-authored graphic design: A strategy for integrative studies. Journal of Aesthetic Education, 36(3), 103-116.

McClean, D. (2009). Embedding learner independence in architecture education: Reconsidering design studio pedagogy. PhD thesis, Robert Gordon University.

Mikropoulos, T. A., \& Natsis, A. (2011). Educational virtual environments: A ten-year review of empirical research (1999-2009). Computers \& Education, 56(3), 769-780. https://doi.org/10.1016/j.compedu.2010.10.020

Milovanovic, J., Moreau, G., Siret, D., \& Miguet, F. (2017). Virtual and augmented reality in architectural design and education: An immersive multimodal platform to support architectural pedagogy. Future Trajectories of Computation in Design, 17th International Conference CAAD Futures.

Mohammed, M. F. (2017). Blended e-learning in the architectural design studio: An experimental model. International Journal of Parallel, Emergent and Distributed Systems, 32(1), S73-S81. https://doi.org/10.1080/17445760.2017.1390103

Nerdinger, W. (1985). Walter Gropius: The architect Walter Gropius drawings, prints and photographs from Busch-Reisinger Museum, Harvard University Art Museums, Cambridge/Mass. And from Bauhaus-archives, Berlin. With complete project catalogue. Cambridge. MA: Busch-Reisinger Museum.

Okechukwu, O. M., \& Eze, F. U. (2011). Understanding virtual reality technology: advances and applications. Advance in Computer Science and Engineering, 53-70. https://doi. org/10.5772/15529

Online Schools Center (2020). Best online schools for Bachelor Architecture degrees 2020. Retrieved from https://www. onlineschoolscenter.com/best-bachelor-architecture/

Orhun, S. (2014). A case study to make use of cross-channel user experience for interactive exhibition design. In H. Gottlieb \& M. Szelag (Eds.), Engaging Spaces: Interpretation, Design and Digital Strategies (pp. 225-231). Warsaw: Nodem.

Ran, Y., \& Wang, Z. (2011). Virtual and augmented reality applications in industrial design. International Conference on Machine Learning and Computing, 252-253. 
RIBA. (2014). RIBA validation. Retrieved from https://www. architecture.com/education-cpd-and-careers/ribavalidation/

Roehl, A., Reddy, S., \& Shannon, G. (2013). The flipped classroom: An opportunity to engage millennial students through active learning strategies. Journal of Family \& Consumer Sciences, 105(2), 44-49.

Saghafi, M. R., Franz, J., \& Crowther, P. (2012). Perceptions of physical versus virtual design studio education. International Journal of Architectural Research, 6(1), 6-22.

Salama, A., \& El-Attar, M. (2010). Student perceptions of the architectural design jury. Archnet-IJAR: International Journal of Architectural Research, 4(2-3), 174-200. https://doi. org/10.26687/archnet-ijar.v4i2/3.104

Schön, D. A. (1987). Educating the reflective practitioner: Toward a new design for teaching and learning in the professions. California: Jossey-Bass.

Schweibenz, W. (2019). The virtual museum: an overview of its origins, concepts, and terminology. The Museum Review, 4(1).

Sharji, E., Peng, F., \& Woods, P. (2013). Experiencing interactive exhibition spaces. 2013 International Conference on Informatics and Creative Multimedia, 330-334.

Sherman, W. R., \& Craig, A. B. (2018). Understanding virtual reality: Interface, application, and design. San Francisco, CA: Morgan Kaufmann.

Shulman, L. (2005). Signature pedagogies in the professions. Daedalus, 134(3), 52-59.

Stewart, A. (2019, July 28). Abu Dhabi named second-most-cultural city in the world by Skyscanner. The National: Arts and Culture. Retrieved from https://www.thenational.ae/artsculture/abu-dhabi-named-second-most-cultural-cityin-the-world-by-skyscanner-1.891589\#: :text=Abu\%20 Dhabi\%20made\%20it\%20to,capital\%20of\%20ltaly's\%20 Tuscany\%20region

Stratigakos, D. (2016). Where are the women architects? Princeton: Princeton University Press. 
Su, C., Yen, B., \& Zhang, X. (1998). An internet based virtual exhibition system: Conceptual design and infrastructure. Computers \& industrial engineering, 34(3-4), 615-618. https://doi. org/10.1016/S0360-8352(98)00172-7

The Open University of Catalonia (n.d.). Retrieved from https://www. uoc.edu/portal/en/index.html

The Open University (n.d.). Retrieved from http://www.open.ac.uk/

Ubell, R. (2016, December 13). Advice for faculty members about overcoming resistance to teaching online. Inside Higher Ed. Retrieved from https://www.insidehighered.com/ advice/2016/12/13/advice-faculty-members-aboutovercoming-resistance-teaching-online-essay

vdf. (2020). Dezeen. Retrieved from https://www.dezeen.com/vdf/ schools/

Webster, H. (2006). A Foucauldian look at the design jury. Art, Design \& Communication in Higher Education, 5(1), 5-19. https:// doi.org/10.1386/adch.5.1.5_1

Webster, H. (2008). Architectural education after Schön: Cracks, blurs, boundaries and beyond. Journal for Education in the Built Environment, 3(2), 63-74. https://doi.org/10.11120/ jebe.2008.03020063

WHO. (2020). Coronavirus disease 2019 (COVID-19) situation report 52. Retrieved from https://www.who.int/docs/defaultsource/coronaviruse/situation-reports/20200312-sitrep52-covid-19.pdf?sfvrsn=e2bfc9c0_4

Wojtowicz, J. (1995). Virtual design studio (Vol. 1). Hong Kong: Hong Kong University Press.

Zayed University (n.d.). College of Arts and Creative Enterprises. Retrieved from https://www.zu.ac.ae/main/en/colleges/ colleges/_college_of_arts_and_creative_enterprises/ index.aspx 